https://helda.helsinki.fi

\title{
The Language of Giving in Theology
}

\section{Saarinen, Risto}

2010-10-31

Saarinen, R 2010 , ' The Language of Giving in Theology ' , Neue Zeitschrift für

systematische Theologie und Religionsphilosophie. , vol. 52 , no. 3 , pp. 268-301 . https://doi.org/10.1515/NZST.201

http://hdl.handle.net/10138/41873

https://doi.org/10.1515/NZST.2010.018

acceptedVersion

Downloaded from Helda, University of Helsinki institutional repository.

This is an electronic reprint of the original article.

This reprint may differ from the original in pagination and typographic detail.

Please cite the original version. 
The Language of Giving in Theology

\section{Risto Saarinen}

Among contemporary thinkers, fascinating theological insights to giving and the gift have been provided by Jean-Luc Marion, Bo Holm, Jan-Olav Henriksen, Ingolf Dalferth and Oswald Bayer. The French Catholic philosopher Marion has constructed an elaborate Christian philosophy around the concept of givenness. He considers that the excessive, superabundant character of reality is due to the underlying givenness in which a higher reality overcomes the economic horizon. ${ }^{1}$ Bo Holm has come to the conclusion that the mature Luther understands reality in terms of giving. While Luther's early theology of ascesis and renunciation involved a model of deficit, the Reformer in his mature years began to understand creation and God in terms of giving and the gift. In this new model of divine excess and abundance the proper attitude of the Christian is not one of renunciation but of gratitude. ${ }^{2}$ Jan-Olav Henriksen even concludes his new book with the sentence that "everything is gift". 3

Ingolf Dalferth, on the other hand, has argued that the traditional view of God's monergy in salvation can be defended in terms of God's unilateral gift which in itself creates the possibility of its reception. There is thus no need to understand the theological concept of gift with the help of social reciprocity. Protestant theology should instead conceive salvation as resulting from an unconditional and self-regulating gift which is received purely passively. ${ }^{4}$ Among recent scholars, Dalferth in particular represents the view that the Protestant theology of justification does not allow for reciprocity. All talk of human activity in response to God's initiative belongs to sanctification, not to justification.

Oswald Bayer has claimed programmatically that Luther promotes a theology of divine giving. Bayer employs the expressions "categorical giving" and "categorical gift" to point out that, for Luther, both creation and the new creation in Christ appear as God's gifts in the free and unconditional act of divine giving. ${ }^{5}$ Among confessional Lutheran texts, the exposition of

\footnotetext{
${ }^{1}$ For a concise overview, cf. Robyn HORNER, Jean-Luc Marion: A Theo-logical Introduction (Burlington: Ashgate, 2005).

${ }^{2}$ Bo Kristian HoLM, Gabe und Geben bei Luther (Berlin-New York: de Gruyter, 2006). Ibid., "Justification and Reciprocity. 'Purified Gift-Exchange' in Luther and Milbank", in Word-Gift-Being: Justification-Economy-Ontology, ed. Bo Kristian HoLM and Peter WIDMANN (Tübingen: Mohr Siebeck, 2009), 87-116.

${ }^{3}$ Jan-Olav HENRIKSEN, Desire, Gift, and Recognition. Christology and Postmodern Philosophy (Grand Rapids: Eerdmans, 2009), 367.

${ }^{4}$ Ingolf U. DALFERTH, "Mere Passive. Die Passivität der Gabe bei Luther" in HoLMWIDMANN (see above n. 2), 43-72.

${ }^{5}$ Oswald BAYER, "Schöpfungslehre als Rechtffertigungsontologie”, in HOLM-WIDMANN (see above n. 2), 17-42; ibid., "Ethik der Gabe", in Die Gabe - ein "Urwort" der Theologie?, ed. Veronica HOFFMANN (Frankfurt: Lembeck, 2009), 99-123.
} 
the Creed in Luther's Large Catechism has often served as a textual basis of the Protestant theology of divine giving.

All these authors prefer a theological method which could be characterized as historical and phenomenological. They are interested in the theological phenomena of gift and giving and compare these phenomena with sociological, philosophical and historical models. Especially Marion and Holm but also Bayer consider the phenomena of giving and receiving as highly animate and personal realities; in these phenomena, the universe witnesses the traces of its personal Creator. The experience of personal, abundant and even excessive character of reality is a highly remarkable theological issue. At the same time I believe that the current discussion has not properly understood the nature of this experience. It is a real experience but it is also deeply embedded in the very essence of human language. A closer look at the language of giving will solve many puzzles related to the issues of the gift and reciprocity.

This paper wants to bring about a "linguistic turn" in the current theological discussion on gifts and giving. In the following, I will first focus on the linguistic constructions around "give". Then I will enrich the linguistic approach with the help of Seneca's philosophy of gifts and services. I will not, however, interpret Seneca's De beneficiis as a handbook of anthropology and economic exchange, but as a guide to the proper use of the words "give" and "receive". In the last sections of this paper, I will discuss some prominent themes of Reformation theology from the linguistic perspective of giving. In particular, I will address the issue of receiving something purely passively.

Model One: The Ditransitive Construction

In grammar, verbs can be distinguished according to their places, that is, how many other grammatical items they need in order to become a sentence. In English, "die" exemplifies a one-place verb which only needs a subject. Transitive sentences, such as

\section{a. John kills Mary}

employ a two-place verb which requires a subject and an object. Most English verbs, as most verbs in any language, are either one-place or two-place verbs. Generally speaking, one-place verbs are intransitive and two-place verbs transitive. ${ }^{6}$

In English, as in most other languages, there are also three-place verbs which take two objects. In grammar, they are called ditransitives. In the sentence

b. John gave Mary a book

the verb "give" is ditransitive, taking "Mary" as its first and direct object and "book" as its second, indirect object. The same sentence can also take the form c. John gave a book to Mary.

\footnotetext{
${ }^{6}$ There are also zero-place verbs, as in the German sentence "Es regnet." I consider "es" and "there" (e.g. in the one-place expression "there is faith") to be "dummy" words which do not occupy a grammatical place.
} 
For the sake of simplicity, I will treat these two forms as synonymous. Following contemporary linguistics, I will label the first object of "give" as recipient and the second object as thing. Other strictly ditransitive verbs include, for instance, "show". Many verbs can sometimes be employed in a ditransitive fashion. For instance, "Chris baked a cake" uses "bake" as a two-place transitive verb, whereas "Chris baked Pat a cake" employs it as a three-place ditransitive. ${ }^{7}$

In a recent study of ditransitive sentence constructions, Adele Goldberg claims that "give" is nothing less than the prototype of this construction:

Give, however, is the most prototypical ditransitive verb because its lexical semantics is identical with what is claimed here [in her study] to be the construction's semantics. ... In fact, I performed an informal experiment to gauge the strength of the intuition that give codes the most basic sense of the construction. I asked ten nonlinguists what the nonsense word topamased meant in the following sentence:

"She topamased him something."

A full six out of ten subjects responded that topamased meant "give". This fact cannot be attributed simply to effects of general word frequency because there are several other words allowed in this construction that are more frequent than give [e.g. make, get]. ${ }^{8}$ Golberg aims at showing that the meaning of a word is in many ways determined by the syntactic construction in which it serves as a placeholder. The meaning of "give", for instance, is not determined by this word alone, but by the ditransitive construction in which it occupies a prototypic role.

Linguists also argue that there are four-place verbal constructions in which a tritransitive verb is employed. Examples include

d. John gave Mary the book for Tom, and

e. Tom made John give Mary the book.

In d, linguists call the fourth place ("for Tom") that of a beneficiary; in e ("Tom made"), that of a causee. A tritransitive thus consists of four placeholders: an agent, a thing, a recipient and a beneficiary (or causee). ${ }^{9} \mathrm{D}$ and e are not synonymous; we could say that a causee adds one more effective cause to the act of giving, while a beneficiary adds a further purpose or teleological cause to it.

In some verbs, like "give" a ditransitive structure is inevitable: the construction needs to have all three components, the agent, the thing and the recipient. The fourth component is not obligatory in the same sense as the first three. The placeholders are normally called arguments

\footnotetext{
${ }^{7}$ See Adele E. GoldBerg, Constructions: A Construction Grammar Approach to Argument Structure (Chicago: University of Chicago Press, 1995), 34-35, 141-151. ${ }^{8}$ GOLDBERG (see above, n. 7), 35-36.

${ }^{9}$ Seppo KITTILÄ, “A typology of tritransitives: alignment types and motivations” in Linguistics 45 (2007), 453-508. I am indebted to my Helsinki colleague in linguistics, Matti Miestamo, for drawing my attention to these matters. My account of the linguistic facts remains simplified and rudimentary.
} 
and linguists claim that "the [maximum] number of core arguments per clause is three" ${ }^{\prime 10}$ In other words, no verb needs more than one subject and two objects. Some verbs, like "give" can take a third object, but it is no longer a core argument. Therefore, the theological ditransitive sentence

f. God gave his son to death

does not need to be extended grammatically. But it can be extended, for instance:

g. God gave his son to death for you (beneficiary tritransitive), or

h. You made God give his son to death (causee tritransitive).

Although tritransitives are syntactically less established than ditransitives, they have also received an increasing amount of attention in current linguistics.

The meaning of "give" is embedded in the particular ditransitive sentence construction. It is not, however, altogether easy to explain how this meaning emerges out of the syntactic construction. Without going too much into linguistic detail, I will outline two simple models of this emergence of meaning. ${ }^{11}$ The first one could be labeled as a reductionist interpretation of "give", whereas the second employs "give" as a basic verb. While my final theological preferences will be attached to the second model, the first model is in its own way very useful for understanding the fundamental features of "give". Although my discussion remains limited to the English language, both linguistic theory and the empirical evidence collected by linguists offer strong support for the view that the ditransitive construction is fairly universal. The features explained in the following are therefore assumed to apply to biblical languages and Latin as well as to English, German and French.

As to the first model, two grammatical concepts need to be introduced. The concept of animacy, that is, whether the placeholder is a living subject and capable of some kind of agency, is not only relevant for the word occupying that place but also for the whole construction. Transitive verbs, for instance, very often require an animate subject because they express agency. The ditransitive places of agent and recipient are normally occupied by animate placeholders; this is a semantic feature of the grammatical construction. ${ }^{12}$

The concept of causativity is another semantic feature which is often attached to syntactic constructions. Usually the shift from intransitivity to transitivity requires an attachment of causativity and, when a human agent acts intentionally, volitionality to the construction. ${ }^{13}$ Thus "a tree falls" can be made causal by saying that "the worker felled the tree." A causative moment is attached to "Bill dies" by saying that "John kills Bill." It is important to notice that

\footnotetext{
${ }^{10}$ KitTILÄ (see above n. 9), 501.

${ }^{11}$ The first model is based on the work of John LYONS, Introduction to Theoretical Linguistics (Cambridge: Cambridge University Press, 1975) and GOLDBERG (see above n. 7). The second model is outlined in John NEWMAN, Give: A Cognitive Linguistic Study (Berlin - New York: Mouton de Gruyter, 1996).

${ }^{12}$ LYONS (see above n. 11), 341, 354-356, GOLDBERG (see above n. 7), 141-151.

${ }^{13}$ LYONS (see above n. 11), 352-354. For the sake of brevity, I will not discuss the closely related concept of ergativity but subsume it under causativity, agency and volitionality.
} 
animacy, causativity and volitionality are not merely extralinguistic phenomena referred to by individual words, but they are also embedded in the linguistic construction. ${ }^{14}$ A straightforward constructionist could even claim that these important categories are primarily linguistic features which may not have counterpart in the extralinguistic world. I do not dare to claim this, but will nevertheless argue that the meaning of these categories is dependent on the grammatical construction in which they are embedded.

Let us formulate the following three intransitive sentences (stage 1):

i. Bill dies

j. A book appears

$\mathrm{k}$. There is faith.

We could then make these sentences transitive as follows (stage 2)

1. John kills Bill

m. Mary has the book.

n. You have faith. ${ }^{15}$

The step from stage 1 to stage 2 adds a causative moment and some animacy into the place of the subject/ agent. The subject of stage 1 becomes an object at stage 2 .

We can then apply causativization for a second time, so that we obtain (stage 3 ):

o. Tom made John kill Bill

b. John gave Mary a book

p. God gave you faith.

The verb "make" expresses causativity, so that in the step from stage 2 to stage 3 "give" in many ways equals "make have". At the third stage we now have two typical ditransitives. Their meaning emerges from ordinary transitives (stage 2) by means of an additional causativization, that is, make+have. An ordinary transitive needs an animate subject which becomes a recipient at the ditransitive stage 3 . We may say ${ }^{16}$ that the meaning of a sentence emerges, by means of successive causativizations, from intransitive (stage 1) to transitive (stage 2) and then to ditransitive (stage 3 ) constructions. When inanimate terms occupy a core argument, they normally serve as intransitive subjects, transitive objects or ditransitive things. In $\mathrm{j}, \mathrm{m}$ and $\mathrm{b}$, for instance, the term "book" occupies these three places. Animate terms can serve in most core arguments. While the thing can be either inanimate or animate, the ditransitive subject and recipient are normally animate. If an abstract word is employed as ditransitive recipient, it is metaphorically personified or animate, as "death" in

f. God gave his son to death.

${ }^{14}$ Cf. GOLDBERG (see above n. 7), 35-39.

${ }^{15}$ I do not discuss the peculiarities of "to have" (for those, LYONS (see above n. 11), 391397 ) but treat it as a transitive verb which often requires animacy and/or causativity in its subject.

${ }^{16}$ Developing the view of LYONS (see above n. 11), 368-370. 
In terms of this reductionist interpretation of "give" we now have, perhaps surprisingly, a preliminary linguistic explanation of the prominent philosophical and theological issue which has been highlighted by different authors, for instance Jean-Luc Marion and Bo Holm. Why is it that the phenomena of giving and the gift create an atmosphere of reciprocity, sociality and activity of both agent and recipient? This is because we speak of these phenomena in terms of ditransitive constructions which normally require at least two animate arguments. In ditransitive sentences both the agent and the recipient are constructed in terms of agency, animacy and causativity, given that the recipient can occupy the place of subject/agent in the underlying mono-transitive sentence.

The mutual animacy and agency of these two core arguments is not, however, due to any mysterious abundance or the enigmatic nature of the thing or gift, but it is simply required by the grammatical rules of the ditransitive sentence construction. Therefore, the notion of the gift is, among other things, a ditransitive linguistic construction in which three core arguments are required. At least two of them express agency and animacy, thus creating an atmosphere of manifold reciprocity. This atmosphere is to a great extent caused by the relatively complex linguistic construction.

It is remarkable that the otherwise profound philosophy of the gift, outlined for instance by Jacques Derrida and Jean-Luc Marion, ${ }^{17}$ has not paid attention to these linguistic fundamentals of giving and the gift. The influential sociological work of Maurice Godelier and Jacques Godbout on the gift ${ }^{18}$ likewise neglects the linguistic dimension of social phenomena. The fruitful theological elaborations of giving and the gift in the recent work of Oswald Bayer and Bo Holm also do not look at the grammatical functions of the so-called datives, cases expressing the recipient of ditransitive action. ${ }^{19}$ I have myself neglected this dimension in my earlier work. $^{20}$

Adele Goldberg argues that the prototypic sense of the ditransitive construction is found in "a highly specific semantic structure, that of successful transfer between a volitional agent and a willing recipient". ${ }^{21}$ For Goldberg the verb "give" does not only require animacy and causativity, but a volitional agency and reception which likewise involves willingness. In this sense agency and volitionality are attached to the very construction. Willingness is not only a psychological phenomenon, but also a linguistic category.

\footnotetext{
${ }^{17}$ For a discussion between Derrida and Marion on these matters, as well as for a general overview of their positions, see God, the Gift and Postmodernism, ed. John D. CAPUTO and Michael J. SCANLON (Bloomington: Indiana University Press, 1999).

${ }^{18}$ Maurice GODELIER, L'enigme du don (Paris: Flammarion, 1996); Jacques GODBOUT, L'esprit du don (Montreal-Paris: La Découverte, 1992).

${ }^{19}$ BAYER, "Schöpfungslehre" (see above n. 5), 21 mentions datives but does not go into linguistic detail.

${ }^{20}$ SAARINEN, God and the Gift (Collegeville: Liturgical Press, 2005); ibid., "Im Überschuss: Zur Theologie des Gebens", in HOLM-WIDMANN (see above n. 2), 73-85.

${ }^{21}$ GOLDBERG (see above n. 7), 151.
} 
If the basic meaning of "give" involves two willing partners and a successful transfer between them, it follows that some other uses of ditransitive verbs are to be read as metaphors of this basic meaning. Goldberg ${ }^{22}$ discusses the following examples:

q. The tabasco sauce gave the baked beans some flavor

r. Jack poured Jane an arsenic-laced martini

s. Bill gave Chris a headache.

Concerning q, we can see that inanimate beings can sometimes be metaphorically described to perform a transfer as if between two animate partners. In the case of $r$, Goldberg remarks "that the recipient to be willing should not be confused with the idea that the recipient is expected to benefit from the transfer". Jane drinks the martini willingly, although it is harmful to her. The distinction between recipient and beneficiary is important in many theological contexts, as we will see below. Concerning s, the willing agent and the successful transfer are sometimes sufficient to legitimize the metaphorical use of "give": although Chris did not want to receive this headache, she nevertheless possessed a certain openness which was enough to bring about a successful transfer as if she were willing.

In sum, Goldberg argues that there is a certain underlying core of meaning in the ditransitive verb "give". This core of meaning is embedded in the very construction which involves a verb and its three necessary core arguments. The core meaning allows for some metaphorical uses of the verb, but the metaphors need to be understood as being based on this core meaning. The core meaning of the construction involves two willing partners and a successful transfer of the thing from the agent to the recipient. The non-linguists should see that this transfer of the thing/gift does not merely describe a sociological or philosophical phenomenon, but it is already in itself a linguistic phenomenon embedded in the ditransitive construction. A consistent analysis of gift-giving should therefore take the linguistic phenomenon of ditransitivity very seriously.

\section{Model Two: "Give" as Basic Verb}

Two objections could be raised to the analysis given above. First, there may be a circular reasoning involved in the claim that the atmosphere of sociality and reciprocity needs to be sought from the level of language. When we want to speak of animate and intentional exchanges, we need to use ditransitive constructions. But this does not mean that the intention and the animacy involved need to be reduced to the linguistic entities. Isn't it rather the case that these are also found in the extralinguistic world of which the language aims to give a true picture? The resources of language do not create the phenomena of sociality and intentionality, but they instantiate it.

Second, the linguistic analysis given above is overly reductionistic, as it claims that even such basic verbs as "give" can be reduced to elementary constituents like animacy, causativity,

${ }^{22}$ GoldBERG (see above n. 7), $146-148$. 
possession and transitivity. Although one can express "give" in many languages in terms of "make have", this does not explain the whole semantics of "give". Shouldn't one rather take "give" as a basic verb and look for the manifold usages of this basic verb? That kind of analysis would yield a much more nuanced and realistic picture of this verb.

Both objections are well founded and deserve serious discussion. The first one leads us into the deep waters regarding the philosophical theory of action. The present paper cannot, however, address the complex issues concerning the fundamental nature of intentions and actions. I am only claiming that such phenomena as animacy, intentionality and volition are already present in the language, and not only as particular words, but also in the fundamental linguistic constructions which all users of language employ. Whether animacy, intentionality and volition are also present in the extralinguistic world is an issue which I will leave undiscussed in this paper. The fact that they are already present in the linguistic construction needs serious attention. For instance, when we speak of God's giving, this linguistic construction already presupposes many things about God irrespective of whether God exists outside of language or not. When I discuss beneficial agency in the following, I do not aim to reduce everything to linguistic constructions, but I will nevertheless focus on how such phrases as "giving oneself" or "receiving" are used in theological texts.

The second objection needs to be conceded. It is true that "give" cannot be completely understood in the reductionist manner of our first model. Its analysis has nevertheless been helpful since it has shown the elementary parts which in most cases belong to this verb and the ditransitive construction around it. The analysis given above can thus serve as a necessary introduction to some basic features of the ditransitive construction, but it does not provide an adequate understanding of the many faces of the verb "give". As my second linguistic model, I will therefore provide John Newman's recent comprehensive analysis of this verb in its literal and metaphorical uses. For the sake of brevity, I will limit my discussion to English usages, but Newman has in fact collected a rich range of evidence from many languages to show that the basic features of "give" remain fairly consistent in different languages. ${ }^{23}$ Given this evidence, we can plausibly argue that the basic semantics of "give" in biblical languages as well as in Latin and German comes fairly close to Newman's results.

${ }^{23}$ John NEWMAN, (see above n. 11). 
Newman considers "give" to be a so-called basic verb which is needed to build many more sophisticated and differentiated verbs and phrases. He approves the view that constructions with "give" typically involve the giver, the recipient and the thing transferred. The basic prototypical sense of "give" can be understood as passing an object from one person to another person. $^{24}$ This comes close to Goldberg's view, with the notable difference that Newman does not include volitionality. But the presupposition of persons clearly indicates that the interaction involves animacy and certain intentionality.

The fuller meaning of "give" can be established through references to four cognitive domains which together establish a complex matrix of this meaning. They are 1) the spatiotemporal domain, 2) the control domain, 3) the force-dynamics domain and 4) the domain of human interest. ${ }^{25}$ While the spatio-temporal domain describes the transfer of the thing over space and time, the control domain depicts the transfer of the thing from the giver's control to the recipient's control. The force-dynamics domain understands the act of giving as a flow of energy from the giver to the recipient. The domain of human interest interprets giving in terms of the benefactive and adversative effects of this action: in a standard case, the act of giving has a benefactive effect on the recipient.

The domains overlap in many ways: when I give this book to you, I also lose my control over it $(1,2)$. When God gives the Spirit to Christians, the Spirit both empowers and sanctifies the recipients $(3,4)$. According to Newman, the meaning of "give" in its different uses is built upon a complex network of these four cognitive domains. Although Newman considers the domain of human interest to belong to the basic ditransitive meaning, he discusses the commonalities and differences between recipients and beneficiaries, coming to the conclusion that they have much in common. ${ }^{26}$ In many ordinary acts of giving, the recipient clearly benefits from this act. In English, the domain of interest can be highlighted with the preposition "for": while "I give this to you" primarily involves domains $(1,2)$, "this is for you" underlines (4). Sometimes the beneficiaries are clearly distinct from the recipients, as we saw in our discussion on tritransitives, but Newman claims that even in the ordinary act of "giving to", a benefactive "for you", that is, for the benefit of the recipient, can often be heard. The recipients can, accordingly, sometimes be thought of as possessors, sometimes as beneficiaries, depending on which domain is highlighted.

\footnotetext{
${ }^{24}$ NEWMAN (see above n. 11), 34-35.

${ }^{25}$ NEWMAN (see above n. 11), 37-53. This is not an exhaustive or exclusive set of meanings. Embedded in the prototypical sense is, e.g., a strong directionality which is expressed in many idiomatic usages like "give away", German "hingeben" etc. For these, see NEWMAN (see above n. 11), 22-23. See also John NEWMAN (ed.), The Linguistics of Giving (Amsterdam: John Benjamins, 1998). This volume contains on pp. 307-325 NEWMAN's article "The Origins of the German es gibt Construction" which is also relevant for some philosophical theories of the gift.

${ }^{26}$ NEWMAN (see above n. 11), 211.
} 
In addition to these four domains, Newman identifies several categories which enable constructions with figurative "give". Such categories include a) interpersonal communication ("give advice"), b) emergence of entities ("give milk"), c) causatives (giving a hug), d) permissions ("give someone to think") e) schematic interaction, f) benefactive marking, g) movement, h) completedness. ${ }^{27}$ Newman discusses extensively in which sense the benefactive markings (f) in certain constructions represent a figurative "give". While in domain (4) of literal "give" the benefactive effect concerns the recipient, in (f) even other benefactively marked members of the construction can be grasped as recipients. Newman's main point is to say that "the two concepts of recipient and beneficiary weakly imply each other, even though they may be distinguished conceptually". ${ }^{28}$ This means that even in tritransitives like "John gave Mary the book for Tom" or "God gave his Son to death for you" the beneficiaries (Tom, you) are at least weakly implied to be also figurative recipients. Moreover, in phrases like "this is for you" an act of giving with its recipient is implied.

Newman's picture of the meaning of "give" in terms of cognitive domains and figurative extensions does not dramatically change the view of giving achieved in our first model. The same constituents of the ditransitive construction are employed, and the prototypical meaning is seen as the transfer of a thing from one person to another. Various non-standard uses of "give" are interpreted as figurative extensions. The literal meaning of "give" has fairly stable domains which describe the transfer from four different but often overlapping cognitive perspectives. Two important new nuances need, however, to be taken into account: (i) although the transfer takes place between persons, their activity need not be defined in terms of volition. Instead, Newman introduces more nuanced variants of agency. While the four domains depict the giver in terms of fairly strong activity (moving away from, losing control, energy source, benefactor), the recipient need not display much activity. To some extent, the same is true of intentionality. At least in the domains of control and human interest, a fairly strong intentionality is presupposed from the giver and some, though not necessarily much, intentionality from the recipient. And (ii) the domain of human interest is particularly interesting, since it connects the recipient with the beneficiary. In ordinary acts of giving, a benefactive effect on the recipient is often presupposed. And the other way round, literal beneficiaries are often thought of in terms of figurative recipients. While keeping this mutual weak implication in mind, it is nevertheless important to retain the conceptual distinction between the recipient and the beneficiary.

This closer look at the meaning of "give" allows us to proceed towards theological variants of giving. Before doing that, we will still refine the concept of beneficiary through a look at a prominent historical source in which the activity and intentionality of the giver and the recipient/ beneficiary is extensively discussed. We will see that in beneficial giving the difference between the activities of the giver and the recipient-beneficiary becomes significant.

\footnotetext{
${ }^{27}$ NEWMAN (see above n. 11), 133-252.

${ }^{28}$ NEWMAN (see above n. 11), 219.
} 
Although we now move from linguistics to philosophy, the use of certain basic concepts remains in focus.

\section{Givers, Recipients and Beneficiaries: Seneca}

The concept of beneficiary is employed in a particularly rich and many-sided manner in theological sentences in which it helps to formulate the central doctrines of atonement, sacrifice and the eucharist. The linguistic level of di- and tritransitives is basic for the understanding of these doctrines, but at the same time this level remains too rudimentary. A more precise meaning of this concept is established in the Western philosophical tradition. I will employ Seneca's De beneficiis (On Favours, ben) as my paradigmatic example of this tradition. As this book was extensively used throughout the Middle Ages and the Reformation, its understanding of the concept can be taken as representative. ${ }^{29}$ I will translate the Latin beneficium (German: Wohltat) as "beneficial agency", "an act of favour" or simply "favour". A beneficium is normally described in terms of a tritransitive construction which includes four arguments: the beneficial agent, the thing (gift, vehicle of favour), the recipient and the beneficiary. The overlapping of the two last arguments is particularly important in discussing favours.

In some acts of favour, as in giving money to the poor, the literal recipient and the literal beneficiary are identical. In others, as in giving money to build wells for the poor or in paying the debt of a slave, the literal recipient differs from the intended beneficiary. This difference can often be expressed in terms of two recipients: in releasing the slave, the slave-owner receives an economic transaction, whereas the slave receives the favour of release and becomes a beneficiary. In this sense, a beneficiary is the recipient of favour, although he or she need not be the recipient of the concrete thing/gift. An act of favour is performed for the definite purpose of helping somebody. In order that a simple act of "giving to" qualifies as an act of favour, it needs to contain a clear purpose or intention which makes it an act of "giving for". Acts of favour thus depict a category of giving in which the beneficiary is often thought of as the recipient. The domain of human interest thus becomes the primary domain of this discussion. Let us look closer how Seneca formulates these principles.

For Seneca, favours need to be advantageous, but not all advantages received are due to acts of favour. Acts of favour need, first, to be significant enough; very small and ordinary

\footnotetext{
${ }^{29}$ The excellent new English translation in SENECA, Moral and Political Essays (Cambridge: Cambridge University Press, 1995), does not include the sixth book which is important in the following. A complete text is found in SENECA, Moral Essays III (LCL 310, Cambridge Mass.: Harvard University Press, 1935). For introductory information about the significance of this work, see Francois-Regis CHAUMARTIN, Le De beneficiis de Seneque, sa signification philosopique, politique et sociale (Paris: Les belles lettres, 1985); Miriam GRIFFIN, "De Beneficiis and Roman Society", The Journal of Roman Studies 93 (2003), pp. 92-113 and Troels ENGBERG-PEDERSEN, "Gift-Giving and Friendship: Seneca and Paul in Romans 1-8 on the Logic of God's charis and Its Human Response", HTR 101 (2008), 15-44.
} 
advantages are no favours, even though they could be very useful at a given moment (ben 4, 29, 2). Second, and most importantly, "I must further be acting for the sake of the person for whom the favour is destined, I must judge him worthy and be glad to bestow it" (ben 4, 29, 3). The beneficial agent must, in other words, practise intentional and targeted giving, having the purpose of helping the recipient of the favour. This condition of targeted volitionality also means that the act of favour does not essentially consist in the gift or other vehicle of favour, but the real favour occurs in the will of the beneficial agent (ben 1, 5, 1-2; 6, 9, 3). Even when the gift is lost, the will ${ }^{30}$ remains and thus also the real favour (ben $6,2,1-3$ ).

The second criterion presupposes that the recipient of a favour is "worthy" (dignum, ben 4, 29,3 , cf. 4, 28, 1-2, 5). In a normal case this means that the recipient is a rational and voluntary being who can express gratitude. Through being grateful the recipients show that they have received the favour properly; one should not normally perform acts of favour to the ungrateful (e.g. ben 4, 28, 6). This requirement of reciprocity has some similarities to Goldberg's linguistic criterion: a paradigmatic act of giving requires two willing partners and a successful transaction between them.

For Seneca, however, beneficial agency represents a complex case of reciprocity. There is a significant difference between the volitionalities of the beneficial agent and the recipient of the favour. The volitionality of the beneficial giver is always required and even maximized through a number of conditions. For instance, it is not enough that something is done pro me if it is not done propter me. I may receive some non-intentional advantages, but only those advantages that are consciously done for my sake (propter me) qualify as acts of favour (ben 6, 19, 5 - 20, 2 ). If somebody wants to do me a favour, it should not only be advantageous for me, but the beneficial agent should will it (debet non tantum prodesse, sed velle, ben 6,8,3). Therefore we do not receive favours from animals, trees or rivers, although they are in many ways advantageous for us (ben 6, 7, 3).

Seneca makes several important concessions concerning the expected reaction of the recipient of a favour. Although the beneficial agent should normally judge that the recipient be worthy and grateful, there are cases in which one can and should perform acts of favour to the ungrateful. The beneficial agent should then think of a further purpose, such as the worthy relatives of the ungrateful (ben 4, 30-32). "There are times, therefore, when I will give things to the ungrateful, but not for their sakes." (ben $4,32,4$ ). The purpose of "giving for" may thus be broadened beyond the scope of the immediate beneficiaries.

Seneca also allows for the acts of favour which are not recognized as such by their recipients. He even grants that there are favours which are actively unwilled and resisted by their

\footnotetext{
${ }^{30}$ Augustine is often considered to be the father of the concept of will; see e.g. Albrecht DIHLE, The Theory of Will in Classical Antiquity (Berkeley: University of California Press, 1982). Long before Augustine, however, Seneca in De beneficiis highlights the concept of voluntas and the fact of willing as the criterion of intentional acts. The freedom of the will is discussed in ben 6, 21-23.
} 
recipients. In Seneca's Latin, giving and receiving are normally expressed with the verbs dare and accipere. It is possible for Seneca to "receive" (accipere) something without even knowing this to be the case: "One can receive a favour without knowing it, but nobody can receive a favour from an ignorant giver" (ben 6,8,1). Parents, for instance, can educate their children with discipline and even such force which goes against the will of the children. Nevertheless these parental gifts are "the greatest favours" which "we receive when we are ignorant and do not want them" (accepimus dum nescimus aut nolumus, ben 6, 24, 1-2; cf. 7, 31, 4).

Divine acts of favour exemplify a similar pattern: we should be grateful to gods for the sun and the moon and for all other worldly goods. The divine powers have with their eternal will commanded that they be as they are (ben $6,23,1$; cf. 4, 28, 1). They have intentionally organized all these goods so that they can be helpful for the human beings. When we receive (accipimus) these goods, the gods and personified nature as beneficient givers know that we receive them; therefore these goods are real favours of which humans should be grateful (ben 6, 23, 3-4). "The nature paid attention to us before it made us" (ben 6, 23, 5). Such divine works are true acts of favour even when humans remain ignorant of them or claim that they do not want to have them (ben 6, 23, 8; 7, 31, 2-4).

The very last passages of De beneficiis give a vision of how one should treat the ungrateful recipients. One should not think that one has "lost" a favour if the recipient does not react. Even worse is to remind the recipients of their debt of gratitude, since this turns an uncertain friend to a certain enemy. It is much better to continue to act like a beneficial friend, since a pertinent goodness can heal the recipients so that they finally begin to feel gratitude. This is how gods bestow favours: when the recipients remain ignorant and do not react or even when they complain against gods, the divine powers nevertheless continue to act beneficially. The gods are like parents who smile to the complaints of their infants, and we should imitate this divine behavior. The ungrateful person only harms himself through his lack of gratitude. The beneficial agent should continue to act beneficially, targeting his next acts even more carefully. With this pertinent method the beneficial agent can finally improve the infertile soil of the ungrateful recipient so that he becomes more worthy $(7,30-7,32)$.

In this manner Seneca teaches a peculiar reception of favours: even those who do not know about favours or actively resist them, have in fact "received" (accipere) favours. To "receive" a favour in this manner, it is enough that the person has the theoretical possibility and the moral duty to be grateful. One can receive a favour now and be grateful later, as the children who only after many years admit that their education was beneficial. Compared to Goldberg's linguistic requirements, much more is philosophically required from the beneficial giver (targeted act with a purpose), but significantly less from the recipient-beneficiary. Newman's linguistic domains of "give" are, however, more consistent with Seneca's discussion, since Newman does not require a willing recipient.

At the same time, we cannot claim that all reciprocity has vanished from Seneca's discussion. Even when being ignorant, unwilling or ungrateful the recipient-beneficiary has the 
possibility to change his or her mind later and thus show proper reception. This potential reciprocity is enough to fulfill the condition that the beneficial agent should consider the recipient's worthiness. In some cases a continuous flow of carefully targeted favours in itself brings about the expected but delayed reaction through educating and transforming the mind of the recipient. A delayed or potential reciprocity thus corresponds to the conscious, intentional act of favour. Thus there is some reciprocity, but it surpasses the normal boundaries of mutual economy.

A beneficial act is for Seneca not essentially defined in terms of reciprocity or an economy of the gift. What counts primarily is the targeted intention of the giver. Secondarily, the act in question should be significant and somebody should at some later point in time recognize this act as having been beneficial. Although it is proper to react to the acts of favour with gratitude, these acts can also, therefore, proceed in a fairly monergist fashion.

Looking back at our linguistic discussion, we can compare this with linguistic cases like "Bill gave Chris a headache" in which an unwilling recipient with a certain openness is assumed. In spite of Newman's nuanced observations, we may say, however, that the linguistic discussions on ditransitive acts do not pay sufficient attention to the discrepancy between the activities of the giver and the recipient. For Seneca's definition of favours, this discrepancy is of constitutive importance. While favours can be received passively, they need to be given actively and intentionally.

We may summarize our linguistic and historical findings as follows: the verb "give" presupposes a ditransitive construction in which a thing is transferred from one person to another. As persons, the giver and the recipient need to be animate and at least the giver needs to act intentionally. While the recipient is conceptually different from the beneficiary, even ordinary acts of giving tend to have some beneficial effect on the recipient. In constructions using "give" the roles of recipient and beneficiary are distinct but they also weakly imply each other. When we add Seneca's historical discussion on favours (beneficia) to these linguistic considerations, we see that in this sub-species of giving the recipient and the beneficiary are strongly overlapping concepts and can in many, though not in all, respects be considered as identical. In beneficial agency, the intention of the giver constitutes the meaning of the teleological act of "giving for". The recipient-beneficiary should receive favours properly, with willingness and gratitude, but this is a moral rather than philosophical-conceptual condition. While the beneficial agent always needs to have proper intention, favours can also be received without knowledge or volition. Some animate openness is needed from the recipient, but its criteria are low and open-ended.

Recipients and Beneficiaries in Forensic Justification

Moving to theological variants of giving, let us first consider the sentence

t. Jesus gave himself to death for you. 
As a linguistic construction, $t$ is a tritransitive in which "Jesus" is the agent and the thing, ${ }^{31}$ "death" is the recipient and "you" the beneficiary. In the New Testament, tritransitive constructions like this play a significant role in laying out the central Christian message. ${ }^{32}$ The beneficial role of Christ's death is often emphasized; because the position of a beneficiary does not belong to the core arguments of the construction, it needs to be spelled out in order that it can be part of the doctrine. The benefactive "for you" weakly implies that "you" can in some sense be conceived as secondary recipient.

A more complex construction is assumed in sentences in which one of the core arguments is not spelled out, as for instance:

u. God gave his only son for our sake.

In u, "God" is the agent, "son" the thing and "we" the beneficiaries, but the recipient is not mentioned. At least two ways to understand the sentence can be conceived of: First, the recipient is "bracketed", that is, the reader needs to fill its position. It is obvious that the verb "to give" can be used in this manner. Consider, for example, the dialogue: "Did you give Mary the book?" "I gave it already three days ago." The reply does not mention the recipient, but she is obviously presupposed by the speaker. The ditransitive verb can sometimes be used without involving the recipient. Such phrases may occur in some peculiar constructions and circumstances, for instance:

v. Give generously!

w. I gave money for the coma patients.

Normally, however, the ditransitive construction requires all three core arguments. Even in cases like $\mathrm{v}$ and $\mathrm{w}$, a bracketed recipient is assumed. I gave money to some concrete person or agency in order that they can help the coma patients.

Second, we may read, following Newman's advice, the benefactive "for our sake" as weakly implying the recipient. Thus u would mean that God gave his only son to us and for our sake. In the same vein, we could read $\mathrm{w}$ as saying that, because of the weak implication, the money was also given to the coma patients. At the level of language, "giving to" and "giving for" often overlap, but at the same time the two phrases have a slightly different meaning. "Giving to" expresses the basic transfer from one person to another. In terms of Newman's force-dynamics domain, the agent of "giving to" becomes the energy source or the efficient cause of the animate recipient's having the thing/gift. "Giving for", however, expresses a purpose and a kind of teleology or final cause: the act of giving is done for the sake of its beneficiary. When I give you a book, saying, "this is for you", the act can certainly also be described in terms of the

${ }^{31}$ NEWMAN (see above n. 11), 242 summarizes the constructions with personal "thing" as follows: "Common to many of these extensions of the "thing" to a human is the notion of putting the person into a position of being under the influence, authority or control of some entity. This can be seen as reflecting one of the properties of literal "give" which involves putting a "thing" into the sphere of control of the "recipient"." - Already for this reason, identifying the recipient properly is important.

${ }^{32}$ See SAARINEN, God (see above n. 20), 36-45. 
concrete ditransitive "giving to". But at the same time the agent can express a further intention or teleological purpose in saying that the book is "for you". Although the recipient now overlaps with the beneficiary, the ditransitive recipient can also have a tritransitive connotation in that he or she is not only the recipient but also a beneficiary. Although "giving for" deepens and teleologizes the simple ditransitive "giving to", it can also connotate the recipient.

It nevertheless sounds artificial to say that in u God is giving his son "to us" or that the sentence does not need a recipient. It might be debatable whether such biblical sentences as John 3:16 presuppose a recipient ${ }^{33}$ to whom the son is given. At least the doctrinal development which reflects the various positions needed in the atonement presupposes such recipient. Golberg's and Newman's studies on "give" also support the view that this verb prototypically needs a giver, a thing and a recipient. Thus one needs to interpret $u$ as saying that a recipient is assumed and that "we" are primarily beneficiaries. The recipient of $u$ is not "us", although "we" may secondarily and figuratively be thought of under the aspect of receiving something.

Because the biblical language of atonement often emphasizes the beneficiaries but does not spell out the recipient, one can in theological contexts sometimes observe a strong tendency to reduce the role of the recipient to that of a mere beneficiary. In certain forms of Protestantism, this tendency is particularly strong when the primacy and even sufficiency of forensic justification is emphasized. Consider, for instance:

x. You are saved because Christ gave himself for our sake.

According to a strictly forensic interpretation, this pro nobis only means that we are beneficiaries of the theological act of giving taking place between the Father and the Son. This interpretation leads to a group of linguistic and theological problems which need a nuanced discussion. Although Christ might have literally given himself back to the Father, as Anselm of Canterbury claims, ${ }^{34}$ humans also receive something by means of this act of Christ's selfgiving: they are accounted righteous and can be saved on this basis. If we follow Newman's analysis, humans are to some extent figurative recipients of this act of self-giving. And if we follow Seneca's discussion, $x$ expresses benefical agency, and in this sub-species of giving the recipient and the beneficiary are overlapping categories. But this overlapping does not abolish the conceptual distinction between the argumentative places of recipient and beneficiary.

Given this, the adherents of a strictly forensic interpretation may concede that humans can "receive" salvation. But, they continue, this only occurs figuratively, the only literal act of reception being the Son's reception by the Father. The act of $\mathrm{x}$ is, therefore, a genuine tritransitive act in which the literal role of humans is restricted to the role of beneficiary.

\footnotetext{
${ }^{33}$ In SAARINEN, God (see above n. 20), 37, I argue that the recipient in John 3:16 is "the world". But "death" and even "God" could also be thought as recipients.

${ }^{34}$ For an outline of Anselm's theory, see e.g. Jasper HopKINS, A Companion to the Study of St. Anselm (Minneapolis: University of Minnesota Press, 1972), 187-214.
} 
We may compare this doctrine of salvation with the Lutheran doctrine of the Lord's Supper, in which a different, though not completely unrelated, problem appears: concerning the Lord's Supper, it is erroneous for Lutherans to think of humans as mere beneficiaries. The Lutheran criticism of the Catholic mass focused on the issue whether the mass can benefit Christians who do not participate in the mass and receive the eucharist. ${ }^{35}$ In discussing this problem, both the conceptual distinction and the factual connection between recipients and beneficiaries must remain clear: Luther claims that one can only benefit through receiving the sacrament. Private masses, for instance, cannot benefit people who do not participate. In this context, Lutherans maintain that benefiting and receiving belong together. How is this consistent with the doctrine of forensic justification in which the events of benefiting and receiving relate to different persons?

An adherent of the strict view of forensic justification may now argue that the unique selfgiving of Christ in the atonement performs the very thing that the mass cannot perform: the self-giving of Christ to the Father on the cross can benefit all faithful, and it is fully sufficient for the believers to be in the position of the beneficiary. In other words, Christus pro nobis is the only fundamental aspect in the event of salvation. When the bread is distributed with the words "given for you", these words refer to the unique self-giving on the cross. At the eucharistic table, the bread is literally given "to" me, but the deeper beneficial purpose of this act ("for you") refers to the unique event of the cross. Even in the reception of the real presence of Christ in the Lord's Supper, the connection between receiving and benefiting remains secondary, though necessary. The primary position of the Christian remains that of a beneficiary.

Our hypothetical adherent of the strict view could even add that it is semi-Pelagian to claim that the faithful would "receive" Christ in any other way than being a beneficiary. If we are to believe Goldberg's linguistic analysis, the ditransitive construction presupposes that the recipient is a willing partner of a successful transaction. But humans are no willing partners in the event of salvation. The recipient of Christ's salvific self-giving can thus only be God himself, as Anselm's theory of atonement points out. According to the strict view, the faithful only participate in the self-giving work of Christ as its beneficiaries, not as its recipients. As beneficiaries they need not be voluntary partners. In tritransitive sentences, the beneficiaries can be as passive as the coma patients in $\mathrm{w}$. The requirement to receive the eucharist personally does not alter this doctrine of justification, but it remains a secondary requirement which serves the purpose of preventing some other misuses.

Given this, humans remain mere beneficiaries in justification and are saved because God the Father receives the sacrifice of the Son. While in the Lord's Supper you only benefit through receiving, in forensic justification you benefit without receiving any thing or gift. This is because the Father is the only voluntary partner capable of the activity required in the event of

${ }^{35}$ For a comprehensive treatment of these problems, see Wolfgang SIMON, Luthers Messopfertheologie (Tübingen: Mohr Siebeck, 2003). 
receiving the atoning work of the Son. The work of Christ and justification by faith are performed pro nobis, but we are no literal or immediate recipients of these acts of Christ's selfgiving, at least not in the normal linguistic sense of being a voluntary partner.

To discuss this strict view of the sufficiency of forensic justification, we could first ask whether the beneficiary is really as passive as a truly forensic, anti-Pelagian theology of justification assumes. We saw above that the tritransitive construction can in principle take two shapes in which the fourth argument appears as beneficiary or causee as follows:

t. Jesus gave himself to death for you

y. You made Jesus to give himself to death.

In $y$, the beneficiary is turned into a causee so that a causative relationship emerges. As causee the former beneficiary now appears as an active partner in bringing about the aim of selfgiving. The beneficiary "for you" expresses the deeper purpose of this beneficial act. There is some causality involved in the sense of teleology or final cause, but what really counts is the intention of the giver who aims at performing this targeted and beneficial act. Although the semantic relationship between the roles of a beneficiary and a causee is interesting and in some cases both roles can be ascribed to the same person, there is, however, no reason to think of $t$ and y as synonymous. Moreover, as we saw with regard to Seneca, the intended beneficiaries can be as passive as the coma patients of $w$. In this sense the strict view can be defended.

\section{Passive Reception}

The view of the recipient as voluntary partner in the act of giving may, however, be misleading. The theological problem of Pelagianism is connected with the presupposition of a voluntary recipient. Although Goldberg's linguistic analysis claims that the ditransitive "give" needs a voluntary recipient, the more nuanced analysis of Newman shows that the recipient can be fairly passive in some of the domains related to the literal "give". It is often sufficient that the recipient displays some weak intentionality and potentiality to react. In terms of force-dynamics domain, for instance, we can "give" water to the flowers, although the flowers are neither volitional nor intentional agents. The event of "receiving" can emerge with lower criteria than are required for the giver's agency. The same asymmetrical structure between giving and receiving is visible in the philosophical level, as we have seen in Seneca's discussion of favours. The giver needs to be intentional, but the favour can be received in a non-intentional manner - though some potential openness needs to be assumed. In the act of giving, the giver's activity is thus both linguistically and philosophically different from the recipient's activity.

This difference or discrepancy is also reflected in the theological uses of giving and receiving. Seneca teaches that even the ungrateful, ignorant and unwilling "receive" (accipiunt) the favour. This verb is used in the Vulgate translation of 1. Cor 4:7b: "What do you have that you did not receive?" (quid autem habes quod non accepisti). In Western anti-Pelagian theology, this verse has often been employed to downplay human activity, a strategy which is 
remarkably in keeping with the peculiar minimalizing of "reception" in Seneca. Luther, for instance, employs 1 Cor. 4:7 in his Quaestio de viribus et voluntate hominis sine gratia (1516) in this manner. ${ }^{36}$ According to this theological usage, a recipient need not be voluntary or contribute to the act of receiving. In order to refute Pelagianism, one thus need not reduce the role of humans to mere beneficiaries, but one can also argue that there can be instances of a purely passive reception.

As the Latin words acceptio, accipere can in other contexts signify the voluntary freedom of choice or willing acceptance,${ }^{37}$ this non-volitional and passive understanding of "receiving" is significant. The event of "receiving" in Christian theology can be and has often been employed in the orthodox manner of 1 Cor. 4:7 to downplay problematic human activism. Both in Seneca and in theological Latin the verb accipio and its derivatives can mean a fairly passive reception of something, for instance, a favour, a gift or other transaction. The recipient needs to be a person or at least a living being capable of certain openness, but this low amount of activity is already sufficient. If we assume that there can be a theologically unproblematic way of saying that the recipient "receives" salvation, then the so-called "strict view" of forensic justification need not be allergic to all "reception". We may say that in the act of salvation Christ does not only give himself for us, but also to us. This is how the adherents of the so-called effective justification have often read Luther's The Large Catechism.

In his exposition of the Creed in The Large Catechism, Luther reads the second article so that Christ gives himself to us completely. Although the work of Christ is also, and maybe even primarily, performed for us, to overcome sin and the devil, Luther emphasizes that in his work Christ gives himself to us. Since Luther's exposition of the third article deals with receiving Christ as the work of the Holy Spirit, it is theoretically possible to distinguish between justification and sanctification. But the second article, dealing with the work of Christ and with our justification, nevertheless emphasizes that Christ is our Lord who has made us free and, taking us as his own, has restored us to the Father's favour and grace. Our whole salvation and blessedness is based on this second article which, because of such characteristics, does not only describe Christ's work for us, but comprises the entire self-giving of God to us. In this sense Christians are no mere beneficiaries but they also receive the self-giving of God when they believe in Christ as our Lord, as The Large Catechism emphatically points out. ${ }^{38}$

Given that Protestant theology speaks of such receiving, we need to ask how the theological sentence

z. God gives himself to us

\footnotetext{
${ }^{36}$ LUTHER, StA 1, 158, 11-12. Cf. WA 55/2, 889, 33-36.

${ }^{37}$ See e.g. Risto SAARINEN, Weakness of the Will in Medieval Thought, Leiden: Brill 1994, 114-118, 169-171,180-188; Otto Hermann PESCH, Theologie der Rechtfertigung bei Martin Luther und Thomas von Aquin, Mainz: Grünewald 1967, 708-714.

${ }^{38}$ LUTHER, The Large Catechism, BSLK 646-662, esp. 651-653. For a brief comparison of this passage with Seneca, see SAARINEN, "Zur Theologie" (see above n. 20), 79-82.
} 
is to be understood. Does it follow the normal grammar of ditransitive verbs, in which case the human person would become, as recipient, a partner? Or does it postulate a peculiar act of unilateral giving?

One broadly used and in many ways workable solution of the problem of receiving consists in the distinction between justification and sanctification. This distinction plays some role in The Large Catechism and can thus be applied. We could then formulate a more moderate version of the "strict view" of justification as follows: While the faithful predominantly appear as beneficiaries in the event of justification, they can be recipients and even partners in the subsequent event of sanctification. Therefore, justification only occurs pro nobis, but in sanctification we can participate in the self-giving of Christ and even become co-workers in some sense.

One problem of the distinction between justification and sanctification is that it identifies justification very closely with the work of Christ. If the work of Christ consists in the atonement achieved objectively pro nobis and sanctification means the personal appropriation and reception of the fruits of this salvific work, there remains little room between them for the justification by faith as an autonomous doctrine. But The Large Catechism obviously speaks of personal justification, of receiving Christ as our Lord, as the core of the second article. In forensic justification the person is accounted righteous on the basis of Christ's merit. But then this person also appears, at least in terms of grammar and language, in the role of a recipient: he or she receives a gift of releasing the burden, a gift of forgiveness.

"Receiving forgiveness" is a complex theological category. Forgiveness may, ontologically speaking, be an act of "negative giving" in which the sin or debt is annulled, the yoke of slavery is released or the dirt is cleansed. In other words, the person does not receive anything positive, but something is taken from the person. ${ }^{39}$ In spite of this, however, the person grammatically appears as a recipient of the ditransitive divine act of forgiving: the person receives the thing of forgiveness from the giver. As recipient of forgiveness he or she is a genuine recipient of this ditransitive act. In this manner the view of forensic justification cannot escape completely the problem of receiving, at least not if it wants to highlight the justification of the sinner as an act which is based on, but not identical with, the work of Christ. As beneficiaries of the atonement, the believers receive forgiveness. Although forgiveness need not be a positive "gift", it depicts an event of reception which can be grasped in effective terms. We are again witnessing the "weak implication" of Newman: the grammatical argument of beneficiary at least weakly implies some domain of reception.

The moderate version of forensic justification now meets the following problem: while humans only appear as beneficiaries in the atonement and are clearly allowed to be recipients and even willing partners in sanctification, the event of justification appears as a mixed area between them, at least insofar as the grammatical arguments are concerned. While the faithful

${ }^{39}$ See in more detail SAARINEN, God (see above n. 20), 59-79. 
cannot appear as willing partners who voluntarily receive the gift in justification, neither do they appear as mere beneficiaries. In forensic justification, they appear as grammatical recipients of a negative ditransitive act of annulment, release, purification or forgiveness. The demarcation line between justification and sanctification cannot, therefore, be found in the grammatical distinction between beneficiaries and recipients.

But if this is the case, where is this theological demarcation line actually found? To establish such a line, the defender of the moderate view needs to postulate two reception processes, the first of which belongs to justification and the second to sanctification. Grammatically, both deal with the ditransitive actions of giving and receiving. While the first reception of justification depicts an annulment rather than a positive gift, in the second reception of sanctification something is positively given and received. But this means that the demarcation line is, finally, effective and phenomenal rather than forensic or grammatical. We may even claim that the negative gift of release in justification is ontological in the same sense as the positive gift received in sanctification. Given this, there remains a problem in the so-called moderate view of forensic justification.

\section{Receving the Gift mere passive}

The recent volume Word-Gift-Being discusses extensively the understanding of justification in terms of giving and the gift. In this volume both Bo Holm and Ingolf Dalferth defend a variant of effective or ontological justification. Holm argues that some reciprocity or "purified giftexchange" can be found in Luther's theology of justification. In his view, there is no ontological difference between justification and sanctification. ${ }^{40}$

Dalferth defends a position in which justification is distinguished from sanctification and justification is seen as a gift distinct from the gifts of sanctification. Dalferth's aim is not, however, to defend the forensic view of justification or the role of Christians as mere beneficiaries. He considers justification to be a new creation, but this effective reality of justification does not involve any reciprocity. The primary gift of justification differs from ordinary gifts in that it is received without the requirement of being a voluntary partner. Only the secondary gifts belonging to sanctification allow for some human co-operation. ${ }^{41}$

Dalferth's variant of justification is particularly interesting, since he attempts to connect the view of effective justification as a gift of God with the traditional Protestant views of pure passivity and denial of reciprocity. In order to maintain the view of pure passivity, however, he keeps the distinction between justification and sanctification, claiming that in justification no reciprocity occurs. I will now connect my linguistic and philosophical discussions with the view of Dalferth to clarify the nature of human reception in the Protestant doctrine of justification.

\footnotetext{
${ }^{40}$ HOLM "Justification" (see above n. 2); DALFERTH (see above n. 4).

${ }^{41}$ DALFERTH (see above n. 4), bes. 45-49, 54-55.
} 
Dalferth maintains that, for Luther, the divine gift in justification is unilateral and does not allow for any reciprocity or economy of the gift. The gift is received, but the reception occurs mere passive, in complete passivity. We may detect some subsequent activity in the recipient, but such activity occurs entirely a posteriori and belongs to sanctification rather than to justification. Dalferth calls this secondary activity Passivitätsaktivität, ${ }^{42}$ activity from passivity. The reception of the first gift, however, does not require any activity. In the first gift of justification, God the giver creates and establishes not only the gift, but also the requirements its human reception. It is, therefore, the gift itself which transforms its addressee into a recipient. Let us call this kind of gift with the term "operative gift".

Although Dalferth aims at preserving the pure passivity of the recipient, it is also highly important that the grammatical addressee is transformed into a recipient. Only due to this transformation the event begins to resemble giving and can be distinguished from such spatiotemporal acts of transfer, putting and pouring out in which the addressee need not be an animate recipient. At the same time the first gift as a unilateral act resembles these other monergic acts. Dalferth sometimes employs the German verb schenken "pour out, donate" to depict the first act of giving. He also underlines that for Luther the preparatory act of God, a kind of pre-gift, is a "gift of destruction" (Gabe zur Destruktion) or annihilation. ${ }^{43}$ The human resistance must be annihilated before the gift can be received purely passively. The monergic act of justification thus consists, at least conceptually, of two operative gifts, namely, the pregift of destruction and the first gift of new creation in which the addressee becomes a Christian.

After the pre-gift of destruction, the person is nothing, a nihil. The first positive gift of God makes the annihilated person a Christian. With regard to this gift, the recipient remains purely passive. Only after she is made a Christian, can she relate to this new reality and display some activity derived from passivity. In this manner the first gift is an operative gift which also establishes the a posteriori possibility of reciprocity, that is, activity from passivity. ${ }^{44}$ This possibility of relating to some operative gift and to form a judgment concerning it belongs to the realm of the second gift, sanctification, which only becomes an option after the completion of the first gift. ${ }^{45}$ Therefore, all such receiving in which the person forms a judgment occurs in retrospection ${ }^{46}$ and, strictly speaking, belongs to sanctification rather than to justification.

This being the case, the pre-gift and the first gift do not obey Goldberg's grammar of ditransitive sentences which normally require two voluntary partners. Although the event of justification is depicted in terms of gift and giving, the human person does not appear as willing and judging partner in this event. But can Dalferth's discussion remain consistent with Newman's prototypical understanding of "give" as passing a thing from one person to another

\footnotetext{
${ }^{42}$ DALFERTH (see above n. 4), 57.

${ }^{43}$ DALFERTH (see above n. 4), 54.

${ }^{44}$ DALFERTH (see above n. 4), 54-57.

${ }^{45}$ DALFERTH (see above n. 4), 53-54.

${ }^{46}$ DALFERTH (see above n. 4), 47.
} 
person? Or does he in fact reduce the recipient to an inanimate container or addressee which keeps the thing without personally receiving it? Let us first consider this possibility.

Dalferth's description of the recipient's being as "purely passive" approaches some linguistic constructions in which an inanimate addressee or a container is described. We could metaphorically illustrate the first gift with the help of two sentences

aa. I repaired the old suitcase and

bb. put new things in it.

A parallel to Dalferth's reading of Luther would consist in the following:

aa. I repaired the old suitcase and

cc. gave it a new life as my travelling partner.

In cc, the metaphor of giving allows speaking of the inanimate addressee as a transitive object and partner. The metaphor thus works as an operative gift. At the same time, however, the suitcase remains purely passive. Its new life in future stems from an activity derived from passivity in which all secondary activity remains dependant on the giver. The owner may after some time give a retrospective judgment:

dd. After repair, this old suitcase received a new life as my travelling partner.

In terms of this metaphorical illustration, all human judgments concerning justification only occur as retrospective judgments. Although they may afterwards conceptualize the issue at hand in terms of giving-receiving-partnership, the recipient was, insofar as the first gift of repair and new content is concerned, as passive as the suitcase in the illustration.

One problem of such illustrations is that they only work metaphorically, that is, through animating the inanimate object and thus making it a recipient. We have seen that the ditransitive construction normally requires an animate recipient or even a willing partner who receives the successful transfer. As in "the tabasco sauce gave the baked beans some flavor", an inanimate recipient can sometimes metaphorically be described as animate. We may invent other similar animations, for instance, "I gave the tree a hug" or "I gave the stone a hug". Trees and even inanimate stones can in this metaphorical sense "receive" a hug. The human recipient of the operative gift of grace can perhaps be compared to the stone which, in the event of being hugged, metaphorically becomes capable of receiving the hug. In terms of this metaphor, the hug is an operative gift which transforms the stone into a quasi-recipient. Likewise, the tabasco sauce can give the operative gift of flavor to the baked beans so that they quasi-receive this flavor.

Whereas these examples of operative gifts remain metaphorical, the operative gift of justification is not, however, meant to work in terms of metaphor. In order to be an adequate expression of justification, "pure passivity" needs to be compatible with the understanding of the recipient as person and not only as addressee or container. This understanding would also be consistent with the meaning of literal "give" in Newman's analysis. How can this compatibility and consistency be reached? 
In the new creation, the addressee becomes a child of God, an event which can be formulated as:

ee. I gave you the status of childhood.

After this gift is given, the child can relate to this status, but before the gift is given no such reciprocity exists. ${ }^{47}$ In this manner the gift of adoption is an operative gift which also contains the opportunity to receive it. The gift descends on the purely passive addressee. In retrospect, the child of God can judge that he then received grace, but this retrospective judgment is only one aspect of the subsequent Passivitätsaktivität which properly belongs to sanctification. This theological reality can to some extent be illuminated at the linguistic level, but, to capture it more adequately, we need to return to the philosophical discussion of beneficia. I want to argue that Dalferth's position can be supported when we enrich it with the help of this discussion.

Dalferth's analysis of Luther ${ }^{48}$ has remarkable parallels with the classical discussion of gifts and favours, as they are spelled out in Seneca's De beneficiis. We saw above that Seneca considers the normal mode of favours to consist in targeted intentional giving and proper gratitude. At the same time he also allows for such acts of favour in which the recipientbeneficiary remains ungrateful, ignorant and even unwilling. Significantly, he teaches that also such persons "receive" (accipiunt) the favour. We have seen that this verb is used in the Vulgate translation of 1 . Cor 4:7b, a verse also echoed in Dalferth's discussion. ${ }^{49}$

When Luther downgrades human activity in receiving the beneficial act of God, he is not alone in Latin theology and philosophy. Seneca's discussion of divine and parental education as a paradigm of beneficia displays similarities to Luther: the parental favour or first gift is received in a state of ignorance and even unwillingness. The beneficial parent even applies the gift of destruction, namely, coaction and force to overcome the resistance (repugnantia, ben 6 , $24,1-2$ ) of the child. Only in retrospect, that is, after receiving the proper education, can the child become grateful. But the decisive and life-changing beneficium has nevertheless been received much earlier. The parental guidance is also for Seneca a kind of operative gift: the strict education has made it possible that the child can act gratefully in retrospect. Likewise, a careful and continuing bestowal of favours can soften an ungrateful recipient so that he is finally transformed into a worthy recipient (ben 6, 24, 1-2; 7, 30-32). In this manner the classical discussion of gifts and favours does not emphasize reciprocity, but it rather highlights

${ }^{47}$ Cf. DALFERTH (see above n. 4), 53.

${ }^{48}$ It is not possible to discuss here the historical adequacy of Dalferth's presentation. Philipp StOelleger, Passivität aus Passion. Zur Problemgeschichte einer categoria non grata (Tübingen: Mohr Siebeck, 2010), presents the matter in great historical and systematic detail. In my own forthcoming historical study Weakness of Will in Renaissance and Reformation Thought I argue that the old man appears for Luther almost as a non-person, a material to be destroyed and created anew so that God's Spirit adds a qualitatively new element to the human capacity of receiving.

${ }^{49}$ DALFERTH (see above n. 4), 49 alludes to 1 Cor 4:7b. 
the complex monergy of the targeted and intentional beneficial agent. To distribute essential beneficia, it is sufficient to grant the retrospective opportunity of becoming grateful later.

Since this retrospective condition can be fulfilled by delayed reception, the obstacle of permanent ingratitude would only be relevant in the extreme case of such hardening in which not even the repeated application of the operative gift would ever achieve anything. But such hardening is, to return to the terminology of Luther and Dalferth, no longer an instance of that "pure passivity" in which God accomplishes his work on a Christian so that sanctification and Passivitätsaktivität can emerge, often with considerable delay. In this manner it is fully possible to combine the Protestant view of mere passive with the classical discussion of beneficia. It is important to see that Seneca's discussion is not only concerned with the reciprocal return of favours, but he also discusses the complex nature of monergic beneficia and uses it as the model of divine action.

Newman's linguistic domains also point out that the recipient can be understood in different ways: while the domain of control highlights the activity of the recipient, the spatio-temporal domain need not assume the same kind of activity. In many languages, the recipient can appear in terms of goal or locative $;^{50}$ in such construction the activity of the recipient is not in focus. Many constructions of "give" assume the so-called agent-patient model in which "there is an asymmetry with the 'giver' the more agent-like and the 'recipient' the more patient-like". 51 Concerning the relationship between the two verbs "give" and "receive", Newman points out that "we can assume an identical base for both receive and give. With receive, however, only part of that base is profiled: the part involving the interaction of the 'recipient' and 'thing'." other words, when we discuss the phenomenon of receiving, we do not have as balanced a picture of the entire process as when we discuss the phenomenon of giving. It is, therefore, in some ways more proper to discuss receiving in terms of giving. ${ }^{53}$

Taken together, these linguistic observations lend some support to the result that one can discuss passive reception with the help of literal "give". Although the recipient prototypically needs to be a person, the linguistic resources of literal "give" also offer several constructions in which the recipient can appear as a fairly passive addressee or goal of action. While the full claim of significant discrepancy between the activities of the giver and the recipient needs to be grounded in Seneca's philosophical discussion of beneficia, some support for it can already be found in the nuanced linguistic elaboration of "give".

Justification as a Comprehensive Event

\footnotetext{
${ }^{50}$ NEWMAN (see above n. 11), 82-95.

${ }^{51}$ NEWMAN (see above n. 11), 64.

${ }^{52}$ NEWMAN (see above n. 11), 51.

${ }^{53}$ I have developed this point in SAARINEN, “Zur Theologie” (see above n. 20), 78-79.
} 
Thus far I have expressed my agreement with Dalferth's position. Although I think that this agreement is more important than the remaining problems or differences, we may at least have a nominal disagreement concerning the distinction between justification and sanctification.

Why does Luther speak so emphatically of God giving himself "to us" in The Large Catechism, if he thinks that "we" do not even exist at the moment of justification? Does the first gift exemplify "giving" only in the peculiar mode of monergic and operative transfer or pouring out which is experienced as having been received in retrospect? Although such an anti-Pelagian theology underlines God's activity, it also upgrades that reality of sanctification which should, I think, remain secondary. If theology is concerned with our salvation but "we" only come into the picture in retrospect, after the gift of destruction and the first gift of new creation have established "our" existence, ${ }^{54}$ then it follows that all "our" theological reflection and Christian existence necessarily occur in the secondary mode of sanctification and Passivitätsaktivität. If this is the Protestant position, then all its anti-Pelagian striving has only managed to show that Christian existence is in reality concerned with human co-operation, whereas the justification of the sinner is a myth beyond "our" horizon, a tale which "we" can only reflect on in retrospect. $^{55}$

Given this, the doctrine of justification is downgraded into a "pre-season game" or an abstract precondition which is required as a mythic reminder but which does not belong to our daily reality, since "we" as Christians are really concerned with sanctification and activity from our initial passivity. We are here dealing with the phenomenon on which Bo Holm ${ }^{56}$ has focused attention: an exaggerated avoidance of all reciprocity leads to an even worse synergism.

In our discussion, this phenomenon at least partly results from the distinction between justification and sanctification, or between the first and the second gift. Do these two concepts depict two different processes or are they different stages of the same phenomenon? When the believer receives Christ and Christ becomes her Lord, both justification and sanctification are at issue. There are not two really different processes at stake here, that is, one of which would entirely consist of the operative gift of justification, while the other, following the first one, would also allow for an activity from passivity. Let it be granted, on the grounds given above, that from the human perspective it is heuristically useful to distinguish between these two aspects of the one event of receiving Christ: at the initial stage, this gift is entirely operative, but in bringing about the new creation it also creates partnership and even mutuality. At the same time, however, the beneficial agency and its gift remain the same, namely the self-giving

\footnotetext{
${ }^{54}$ With "we" I mean here the identity of the Christians. If this identity is only created in justification and lived in terms of sanctification, the problems of non-reality of justification for this identity begin to emerge. Cf. DALFERTH (see above n. 4), 47, 53-54. ${ }^{55}$ This dilemma is not identical, but shares some similarities with the classical debates concerning the "I" in Romans 7. For these, see. e.g. Stephen WESTERHOLM, Perspectives Old and New on Paul: The "Lutheran" Paul and His Critics (Grand Rapids: Eerdmans, 2004).

${ }^{56}$ HoLM, Gabe (see above n. 2).
} 
of Christ to us so that he may be our Lord. We may compare this agency with the parental education which shapes the child: while the favours bestowed on the child are first met with resistance and only later with gratitude, the continuing process of beneficial agency remains the same; it is only the delayed response which allows making the distinction from the child's perspective.

Thus it would be artificial to claim that "justification is not sanctification", 57 as the operative initial gift already contains the full reality of the divine beneficium, including the potential of receiving the gift (das Empfangenkönnen der Gabe). ${ }^{58}$ The prolongation of this one gift sustains this potential of receiving so that "we" as recipients come into picture. At the same time, the beneficial act of God does not change. Thus the change from the "first" to the "second" gift only concerns our perspectival change while the self-giving of God in Christ remains one. ${ }^{59}$

It would therefore be more adequate to say that sanctification is nothing else than the prolongation of justification. Both terms express the self-giving of Christ to the faithful, the beneficial act of God which contains the deeper teleology of pro me and propter me. I side with Dalferth's claim that some secondary cooperation (Passivitätsaktivität) emerges with the emergence of the new creation. But the justifying beneficial agency of God is not altered in any way by this circumstance; it remains operative and the new person continues to be dependent on the sustaining, targeted will of God even in her new activity from passivity. ${ }^{60}$ But this means that the distinction between justification and sanctification is, finally, redundant or at least secondary. It may help us to understand the perspectival changes resulting in humans in reaction to the divine monergy, but it does not express any distinction in the divine act.

Another and maybe more fruitful way of conceptualizing the theological issue is to call the entire process of Christ's self-giving to us "justification". Then justification becomes a daily reality, with continuous reference to the initial event of baptism as the decisive beginning which is constantly reflected on in retrospect. This particularly Lutheran variant of Protestantism does not highlight ordo salutis and sanctification but it keeps the doctrine of justification and the salvific self-giving of Christ "for us and to us" in its focus. It is entirely possible to safeguard the divine monergy and the retrospective gratitude in this way, without making any distinction in God's agency towards us. Seneca's understanding of beneficia in terms of targeted intentional giving and retrospective appreciation offers a philosophical parallel to the manner of conceiving God's beneficial action as unity.

\footnotetext{
${ }^{57}$ DALFERTH (see above n. 4), 43.

${ }^{58}$ DALFERTH (see above n. 4), 54.

${ }^{59}$ DALFERTH (see above n. 4), 47 quotes WA 40/3, 588, 2-10 in which Luther distinguishes between the first and the second gift. But Luther here also says of the second that "haec etiam est gratia dei et procedit ex primo opere dei", thus underlining the unity of God's beneficial gift.

${ }^{60}$ So DALFERTH (see above n. 4), 58-59.
} 
Let it be added that the dynamics of mere passive and its retrospective confirmation is essentially similar in both "ways" outlined here. My preference of the second way should not diminish the great value of Dalferth's clear analysis of what it means to conceive and to receive justification in terms of pure passivity.

Passivity and Freedom

Some final words can now be said about the relationship of pure passivity to Christian freedom. After the destructive work of the pre-gift, one can speak of a relative freedom from sin and evil. But one cannot speak of freedom of the will, since for Luther only grace moves the will to the good. ${ }^{61}$ The interplay of passivity and freedom is difficult to conceptualize; Luther himself uses different pictures which depict somewhat different aspects of the theological issue. Sometimes he illustrates human passivity with the example of a saw which is solely moved by the sawer. As an inanimate instrument the saw does not have any freedom or activity. ${ }^{62}$ But the justifying faith as human passivity is for Luther a state in which the gift can be given and the new creation can occur. ${ }^{63}$ That kind of passivity can be defined in terms of freedom as openness and possibility of receiving. The passivity of the saw remains different from the passivity of faith, because the latter entails a mode of openness which is not present in the former. Traditionally, as Dalferth also points out, Lutheran theology has claimed that the passivity of the Christian is not comparable to a log of wood or to a stone. ${ }^{64}$ In this sense the Christian can be purely passive and yet display a freedom which distinguishes him or her from a stone or a saw. Our discussion of the genuinely passive "reception" above has also underlined this possibility of passive freedom and openness.

In order to understand the nature of such human passivity, it may be instructive to look again at the linguistic differences between intransitive, transitive and ditransitive constructions. Consider the following sentences:

$\mathrm{k}$. There is faith

n. You have faith

p. God gave you faith

Linguists teach that the transformation from $\mathrm{k}$ to $\mathrm{n}$ and $\mathrm{p}$ occurs through the operations of animacy and causativity. One-place verbs exemplify the simplest construction; when new arguments occupy the place of the subject, earlier arguments move to new places. Thus "faith" becomes the first object in $\mathrm{n}$ and the second object in $\mathrm{p}$. "You" is the animate subject of transitive $n$, but becomes the first object of ditransitive $p$.

\footnotetext{
${ }^{61}$ So DALFERTH (see above n. 4), 58.

${ }^{62}$ DALFERTH (see above n. 4), 59, quoting WA 2, 421, 7-15.

${ }^{63}$ DALFERTH (see above n. 4), 45.

${ }^{64}$ DALFERTH (see above n. 4), 51. Cf. Solida declaratio II, 59 (BSLK 894-896).
} 
We might say that the circumstance of "having faith" in p occurs in terms of both passivity and activity. This observation resembles Dalferth's Passivitätsaktivität. It is passivity because it occurs as corollary to God's primary monergy. But the ditransitive construction p normally requires that the recipient can also take the subject place of the underlying monotransitive construction $\mathrm{n}$. As this place is characterised by animacy and certain causativity, it follows that the circumstance of having faith also needs to fulfill these grammatical conditions.

At this point we may notice a perspectival difference between this kind of linguistics and theology. A reduction-oriented linguist claims that simple constructions (intransitive, transitive) precede more complex constructions (ditransitive). Complex constructions cannot, of course, be derived from simple constructions, since complex constructions add new material (e.g. animacy, causativity, volition). But they can be said to interpret the simple constructions and to qualify them in a new manner, for instance, through adding causatives and animating the subjects so that they become agents. In this sense $\mathrm{n}$ emerges from $\mathrm{k}$ and $\mathrm{p}$ emerges from $\mathrm{k}$ and $\mathrm{n}$. What $\mathrm{p}$ expresses is, linguistically speaking, not a primary passivity but an interpreted passivity which has been constructed in order to understand the simple transitive "You have faith" in a new and richer manner. The ditransitive $\mathrm{p}$ expresses an activity that has been subsequently interpreted in terms of passivity. The sentence $p$ thus represents "activityinterpreted-as-passivity".

Theologically, however, $\mathrm{p}$ is the primary doctrine: there is faith and you have faith only because God first gave you faith. The sentences $\mathrm{k}$ and $\mathrm{n}$ are theological corollaries of the doctrine $\mathrm{p}$, because the underlying transitive and intransitive sentences can be logically derived from the ditransitive sentence. In spite of the perspectival difference it is highly significant that such a derivation can be made. It shows that the underlying sentences have the linguistic potential of applying animate and even causative subjects.

In terms of traditional Lutheran theology, $\mathrm{p}$ should be read as follows:

ff. God gave you faith, thus making you a new creation and a recipient of this faith which is no voluntary activity but a state of pure passivity.

But even this passivity is not equivalent to the passivity of stones. It rather depicts an animate passivity in which you can be a recipient in a sense in which a stone cannot. This passivity instantiates a freedom of openness or, in Seneca's terms, potential gratitude. Although such openness does not involve free will, it allows drawing such conclusions from $\mathrm{p}$ as n. You have faith.

Although the Christian may not have free will or autonomous agency, he or she appears in the realm of language as a subject of transitive sentences, being therefore animate and acting as a secondary partner of God.

The theological primacy of the ditransitive

\section{p. God gave you faith}

implies that this freedom of animacy and co-agency occurs in terms of activity from passivity. This activity remains an activity derived from the primary doctrine $\mathrm{p}$ which shows the human 
person as the passive recipient of divine giving. But if $\mathrm{p}$ is primary or "categorical", 65 the primary event of categorical giving also defines the faithful as a recipient who is capable of these activities derived from his or her primary, categorical passivity. If we take the ditransitive sentences as categorical and primary doctrines, we can derive other sentences from them, respecting the ordinary grammar and semantics of the primary sentences. At the same time, these other sentences only receive their validity from the primary sentences. For instance, gg. You have faith (n) but only because God gave you faith (p).

Your faith is thus not your own doing, but an activity following from the passivity expressed in the primary, categorical doctrine $\mathrm{p}$.

There might even be a way of reconciling the above-mentioned perspectival difference between theology and linguistics. If we do not practice reduction-oriented linguistics but consider "give" as a basic verb, the constructions with this verb look somewhat different. According to Newman's analysis, the recipient of "give" is often considered in terms of goal or patient so that the activity of the recipient does not come into focus, although he or she is considered to be a person. Newman also points out that although "give" and "receive" share an identical semantic base, only a part of this base is profiled when "receive" is treated. ${ }^{66}$ Applied to theological sentences, this can mean that we should look at the nature of human reception from the viewpoint of giving rather than receiving, as the verb "give" encompasses this base in its totality. If sentences with "give" are treated in a non-reductionist manner, that is, as basic sentences in which receiving is not discussed as a separate issue, then we are already very close to the theological perspective formulated above. In this perspective, the recipients can appear in terms of both passivity and such personal openness which distinguishes them from stones.

Another link between passivity and personal openness is provided by Seneca's use of accipere. As we have seen, Seneca considers that one can receive a favour even in the state of ignorance and unwillingness. The semantic criteria of beneficial agency are essentially found in the nature of the giver's action, whereas the closer nature of the recipient of such action remains insignificant for the definition of the concept. On the philosophical level, this consideration again underlines the primacy and basicness of "giving" over "receiving". In other words, the event of receiving is primarily defined through the event of giving. In this sense, the event of giving is not only linguistically but also philosophically a basic event.

In these non-reductionist senses we can use the ordinary linguistic and philosophical meanings of "give" in support of the theological axiom of "categorical giving". In the one event of Christ's self-giving to us we remain recipients, and this means that we display that freedom which follows from passivity but nevertheless differs from the passivity of stones. The basic meaning of "giving something to somebody" thus plays a role in the salvific self-giving of God

${ }^{65}$ To use BAYER's, “Schöpfungslehre" (see above, n. 5), 23, term.

${ }^{66}$ NEWMAN (see above n. 11), 51, 64, 82-95. Cf. above. 
in Christ. This ordinary meaning involves some idea of human freedom as an animate capacity for receiving.

Although such receiving by definition occurs a posteriori and witnesses of God's new creation as being operative in this particular recipient, the event of receiving makes us animate partners in the salvific self-giving of Christ. This reception and partnership always occurs under the precondition of categorical giving. The theological primacy of categorical giving defines the human person as passive recipient of God's action. God's categorical giving liberates the faithful from all their own efforts, but it does not turn them into stones or puppets. Instead, it defines the faithful as animate recipients who have openness and the potential of becoming grateful partners and neighbours. This result leaves my position fairly close to Dalferth, as he also allows for this kind of Passivitätsaktivität.

Instead of seeking support from sociological and anthropological reciprocities, ${ }^{67} \mathrm{I}$ have argued in the present paper that the resources of linguistics and the classical discussion of beneficia already provide sufficient tools for the understanding of that asymmetric process of theological giving which is so characteristic of Protestant theology. The concepts of reception and animate response need not be grounded sociologically or economically, since they are already present in the grammatical construction of the ditransitive "give". While this construction remains basic for the understanding of giving and the gift, it also needs sophisticated historical content available in Seneca's discussion of beneficia. This discussion was historically available in the Reformation; it promotes a view of a targeted, intentional and beneficial giver and a recipient who can "receive" (accipere) even in the state of ignorance and unwillingness.

\section{Summary}

This paper wants to bring about a "linguistic turn" in the current theological discussion on gifts and giving. It focuses on the linguistic constructions around "give" and their use in religious and theological texts. The linguistic approach is enriched with the help of Seneca's philosophy of gifts and services. Seneca's De beneficiis is not, however, interpreted as a handbook of anthropology and economic exchange, but as a guide to the proper use of the words "give" and "receive". In the last sections of this paper, some prominent themes of Reformation theology are discussed from the linguistic perspective of giving. In particular, the issue of receiving something purely passively is addressed.

${ }^{67}$ Cf. above all HoLM, "Justification" (see above n. 2). 